\author{
St udia Philosophic a \\ Wr a t i s l a vi e n s i a \\ vol. XVI, fasc. 1 (2021) \\ https://doi.org/10.19195/1895-8001.16.1.2
}

\author{
PIOTR PRZYBYSZ \\ ORCID: 0000-0001-8184-3656 \\ Uniwersytet im. Adama Mickiewicza w Poznaniu
}

\title{
Estetyka ewolucyjna: między uniwersalizmem a adaptacją
}

\section{Evolutionary aesthetics: Between universalism and adaptation}

\begin{abstract}
The publication of Jerzy Luty's book is a very good opportunity to look at the achievements of contemporary evolutionary aesthetics. In Jerzy Luty's book one can find not only a successful and accurate presentation of the views of E. Dissaneyake and D. Dutton, but also the discussion of a number of difficult problems arising from the analysis of the nature and function of art from the evolutionary point of view. One such problem is undoubtedly the problem of the universalism of art, while another is the problem of art as adaptation. In the paper, I discuss and analyse the original solutions to the problems of universalism and the adaptive nature of art proposed by the author of the discussed book.
\end{abstract}

Keywords: evolutionary aesthetics, universalism of art, adaptive nature of art

Trudno nie zauważyć, że współczesne dyskusje na temat roli i funkcji sztuki podszyte są sporem — niekiedy prowadzonym jawnie, niekiedy dyskretnie — wokół takich opozycyjnych kategorii, jak naturalizm vs. konstruktywizm, uniwersalizm vs. relatywizm, biologia vs. kultura. Spór ten nie jest wcale nowy i ciągnie się przynajmniej od czasu pierwszych kontrowersji dotyczących próby naturalistycznego objaśnienia funkcji sztuki za pomocą mechanizmu doboru płciowego przez Karola Darwina oraz od pojawienia się metod estetyki eksperymentalnej Gustava Fechnera. Mimo braku jakichkolwiek szans na ostateczne rozwiązanie tego sporu wydaje się, że w ostatnich latach w pewien sposób się on nawet wyostrzył. Jednym z powodów było zapewne pojawienie się nowych wersji naturalistycznego 
programu badań nad sztuką, to jest neuroestetyki oraz współczesnych koncepcji z obszaru estetyki ewolucyjnej.

Tym ostatnim koncepcjom poświęcona jest interesująca książka Jerzego Lutego Sztuka jako adaptacja. Uniwersalizm w estetyce ewolucyjnej. Jej autor opowiada się wyraziście i jednoznacznie po jednej ze stron wspomnianego sporu, a mianowicie - za rozumieniem sztuki w kategoriach naturalistycznych i ewolucjonistycznych. Postuluje, aby odwoływać się do teorii ewolucjonistycznych i do empirycznych metod badawczych w celu wyjaśnienia niektórych zagadkowych aspektów sztuki, takich jak na przykład długotrwała jej obecność w historii gatunku ludzkiego, jej pojawienie się we wszystkich kulturach i cywilizacjach, istnienie zmysłu estetycznego czy rola emocji towarzyszących sztuce.

Mimo wyraźnego opowiedzenia się po jednej ze stron sporu naturalizm vs. konstruktywizm autor deklaruje - chyba nazbyt idealistycznie - chęć doprowadzenia do wymiany myśli pomiędzy estetyką tradycyjną a estetyką ewolucyjną. Przywołuje on w tym kontekście koncepcję konsiliencji Edwarda Wilsona i postuluje zbliżenie pomiędzy humanistyką i naukami przyrodniczymi, jakie miałoby się dokonać dzięki estetyce ewolucyjnej pojmowanej jako swoista „platforma interdyscyplinarna" do rozwiązywania tradycyjnych problemów z obszaru estetyki z wykorzystaniem metod będących na wyposażeniu nauk zajmujących się ewolucją.

Tematykę książki zapowiada hasłowo jej tytuł wraz z podtytułem. Przy czym dostrzegam w terminologii tam zastosowanej - chodzi o terminy "adaptacja" i „uniwersalizm” - świadomy i przemyślany wybór autora, gdyż to właśnie między tymi dwiema kategoriami pojęciowymi rozpięta jest niemal cała argumentacja przedstawiona książce.

Kluczowym zadaniem, jakie stawia sobie estetyka ewolucyjna jest mianowicie próba odpowiedzi na pytanie, czy sztuka (resp. praktyki artystyczne, odbiór sztuki wraz z reakcjami estetycznymi, poczuciem piękna, emocjami towarzyszącymi sztuce itp.) jest cechą adaptacyjną w ścisłym lub luźniejszym sensie. Chodzi o to „czy”, „w jaki sposób” i ,w jakim stopniu” uprawianie sztuki daje organizmom przewage przystosowawczą nad organizmami, które sztuki nie uprawiają i czy sztuka przyczynia się do przetrwania naszego gatunku jako całości. Sądzę, że nieco wbrew tytułowi książki — gdzie sztukę uznano za cechę adaptacyjną — autor zdaje sobie sprawę, że „ostateczny” dowód empiryczny na ściśle adaptacyjny charakter sztuki jest dość trudny do przeprowadzenia, między innymi z przyczyn metodologicznych (o czym pisze na przykład na s. 128-129). Jeśli dobrze odczytuję jego stanowisko, nie postuluje on więc sztywno, że sztuka jest adaptacją w ścisłym/wąskim sensie. Wystarcza mu czasami luźniejsze jej ujęcie jako produktu ubocznego, „(by-products, spandrels) innych, starszych ewolucyjnie adaptacji” (s. 128). Jeśli to moje odczytanie jest trafne, to wynika stąd, że tytułowe pojęcie adaptacji potraktowane zostało w książce szerzej niż zwykle się je rozumie i funkcjonuje ono w pracy Lutego jako coś na kształt idei regulatywnej lub pojęcia orientacyjnego, które wskazuje jedynie określony kierunek dla badań prowadzonych w obrębie znaturalizowanej estetyki.

Jednym z argumentów za naturalnym pochodzeniem sztuki — i pośrednio również za jej adaptacyjnym charakterem — jest zaś uniwersalność sztuki, czyli powszechność występowania zmysłu estetycznego i praktyk artystycznych we

Studia Philosophica Wratislaviensia vol. XVI, fasc. 1, 2021

(C) for this edition by CNS 
wszystkich cywilizacjach i kulturach ludzkich. I właśnie uniwersalizm sztuki — pojawiający się w podtytule książki — autor wydaje się uznawać za podstawowe kryterium adaptacyjności (i to mimo że w wielu okolicznościach uniwersalność estetyczna nie jest automatycznym wskaźnikiem biologicznej adaptacyjności). Natomiast kolekcjonowanie empirycznych świadectw uniwersalizmu estetyczno-biologicznego uważane jest za jedno z zadań programu badawczego estetyki ewolucyjnej. Jest to dobrze widoczne, jeśli przyjrzeć się sformułowaniu hipotez 1-7, przyjmowanych przez autora, które pojawiają się w książce na stronach 25-26. Łatwo zauważyć, że spośród siedmiu zaproponowanych tam hipotez, przynajmniej cztery dotyczą bezpośrednio różnych postaci uniwersalizmu estetycznego w wersji naturalistycznej i ewolucjonistycznej. Co więcej, wejrzenie w treść tych hipotez pozwala zorientować się, że proponowane przez Lutego rozumienie tytułowego „uniwersalizmu w estetyce ewolucjonistycznej" jest dość szerokie i obejmuje nie tylko (a) przekonanie o powszechnym występowaniu sztuki we wszystkich kulturach i cywilizacjach (obecnych i historycznych), ale również (b) tezę o uniwersalnym charakterze preferencji estetycznych i (c) takich kategorii jak kunszt i biegłość artystyczna, oraz (d) tezę o występowaniu ponadhistorycznych, międzykulturowych i przedteoretycznych ,uniwersaliów estetycznych" osadzonych w systemie percepcyjno-poznawczym przedstawicieli naszego gatunku i mających ugruntowanie biologiczne (por. s. 24-26).

Ten ostatni punkt ujawnia zresztą pewne uproszczenie, jakiego dokonał autor podczas próby zawężania własnego pola badawczego. Stara się on mianowicie całkiem rozsądnie, jak sądzę, choć zarazem zbyt sztywno, oddzielać wąskie rozumienie estetyki ewolucyjnej, jako badania skoncentrowanego na sztuce i jej praktykach, od estetyki ewolucyjnej w rozumieniu szerokim, zajmującej się również badaniem pochodzenia preferencji i ocen estetycznych. Tymczasem powyższe dwa rozumienia estetyki ewolucyjnej tworzą swoiste kontinuum, przez co są z sobą powiązane w większym stopniu, niż autor w swoich deklaracjach jest skłonny przyznać.

Pierwsze dwa rozdziały książki zainteresują przede wszystkim tych czytelników, którzy poszukują zwartego omówienia tematów i problemów poruszanych przez współczesną estetykę ewolucyjną i — szerzej — pojawiających się w ramach naturalistycznego podejścia w badaniach sztuki. Omówiony tam został skrótowo paradygmat badań ewolucjonistycznych i postawiono pytania o jego stosowalność do tradycyjnych problemów humanistyki (rozdział 1), a także zaprezentowane zostały wyjściowe założenia, na jakich opiera się estetyka ewolucyjna (rozdział 2). Z punktu widzenia głównego zadania książki, jakim jest odnalezienie różnych przejawów uniwersalizmu estetycznego w celu wykazania adaptacyjnego charakteru sztuki, istotne jest tam na przykład omówienie eksperymentu Vitalija Komara i Aleksandra Melamida, którego wynikiem było odkrycie uniwersalnego wzorca preferencji estetycznych promującego widok otwartych przestrzeni i pejzażu sawanny. Przejawia się ten wzorzec na przykład w preferowaniu malarstwa krajobrazowego w porównaniu z niektórymi innymi formami przedstawieniowymi (na przykład malarstwem abstrakcyjnym). Według Lutego prawidłowość ta — występująca wśród ludzi niezależnie od kultury, z jakiej się wywodzą i od miejsca zamieszkania jest istotna, gdyż poprzez nią przejawia się uniwersalizm preferencji estetycznych. 
Kolejny rozdział monografii został w całości poświęcony prezentacji poglądów jednej z głównych przedstawicielek estetyki ewolucyjnej, Ellen Dissanayake. Rozdział ten jest ważny, gdyż koncepcja Dissanayake — obok koncepcji Denisa Duttona - jest stałym punktem odniesienia, do którego autor wielokrotnie powraca w kolejnych rozdziałach. W rozdziale trzecim Jerzy Luty koncentruje się na zaprezentowaniu kilku najważniejszych osiągnięć badawczych autorki Homo Aestheticus. Where Art Comes From and Why. Są to, przede wszystkim, podejście „zachowaniowe” w badaniach sztuki (resp. koncepcja artyfikacji), koncepcja zachowań znakotwórczych (mark-making), oraz koncepcja zdolności proto-estetycznych pojawiających się w ontogenezie (u niemowląt i dzieci). Poglądy E. Dissanayake zostały zaprezentowane przez autora w tym rozdziale w sposób bardzo intuicyjny, spójny i uporządkowany.

Szczególnie interesujący wydał mi się rozdział czwarty monografii, w którym Jerzy Luty podejmuje problem możliwości zdefiniowania sztuki w kategoriach bliskich estetyce ewolucyjnej. Rozdział ten rozpoczyna się od ciekawych rozważań natury analityczno-metodologicznej, w których chodzi o wskazanie na taki typ definicji (i definiowania), który mógłby być wykorzystywany w analizach pojmujących sztukę w sposób adaptacjonistyczny, naturalistyczny i jako „rodzaj naturalny”. Wybór w tym przypadku pada na definicje ,konotacyjne typu skupisko" (s. 112), w których w definiensie wyliczone zostają dysjunktywnie własności, charakteryzujące definiowane zjawisko. Zbiór takich dwunastu cech charakterystycznych sztuki podaje definicja Denisa Duttona, którą autor monografii następnie szeroko dyskutuje. Kłopot z definicjami typu ,skupisko" polega jednak na tym, że dają one zbyt dużą swobodę interpretacyjną przy rozstrzyganiu, czy dane zjawisko podpada pod definicję, czy też nie - co jest szczególnie dotkliwe, gdy w definiensie pojawia się zbyt duża liczba nieostro scharakteryzowanych cech. Ten impas definicyjny próbuje się następnie obejść poprzez wyróżnianie cech „bardziej” i „mniej” ważnych, co jednak podpada z kolei pod zarzut mniejszej lub większej arbitralności. Dutton wskazuje, że taką najbardziej adekwatną i uniwersalną cechą sztuki jest towarzyszace jej „doświadczenie wyobrażeniowe”, natomiast w ramach własnej interpretacji Luty kładzie przede wszystkim nacisk na, również uwzględniane przez Duttona, „biegłość i wirtuozerię". Osobiście zgadzam się z krytykami Duttona (na przykład z Daviesem i Dissanayake), że podany przez niego zestaw cech jest mało przydatny dla wykazania uniwersalistycznego i adaptacyjnego charakteru sztuki, ale równocześnie przyznaję, że propozycja Lutego, aby bronić stanowiska Duttona przez położenie nacisku na „biegłość i wirtuozerię”, jest całkiem ciekawym rozwiązaniem. Muszę natomiast powiedzieć, że rozczarowało mnie zakończenie tego rozdziału, w którym autor proponuje jeszcze jeden sposób na uratowanie definicji konotacyjnej typu skupisko poprzez wskazanie za Duttonem na „potoczne pojęcie sztuki” i ,definicję rodzaju naturalnego". Cały ten fragment jest tak niejasny, że nie potrafię rozstrzygnąć, czy ta próba ratunku przyniosła jakikolwiek pozytywny skutek.

Problematyka ta znajduje swoje przedłużenie w rozdziale piątym, w którym W tym bardzo ciekawym fragmencie Luty przekonuje rozwinacc swój pomysł na „uratowanie” definicji sztuki Duttona i na dostosowanie jej do wymogów ewolucjonistycznego podejścia w oparciu o nacisk położony na cechy związane z biegłością 
i wirtuozerią. Luty przekonuje, że zarzut obiektocentryzmu i etnocentryzmu, jaki postawiła Duttonowi Ellen Dissanayake, można uchylić albo osłabić, jeśli akcent położy się na Duttonowską koncepcję sztuki jako wykonania, gdzie uwzględnia się przede wszystkim kategorie kunsztu, doskonałości wykonawczej i wirtuozerii jako najbardziej uniwersalnych cech praktyki artystycznej. Najciekawszy, moim zdaniem, wątek z tym związany dotyczy tego, w jaki sposób kunsztowność i związany z nią wzrost nakładów pracy twórczej (czyli kosztowność) są rozpoznawane przez aparat percepcyjno-poznawczy odbiorcy sztuki. Autor przekonująco moim zdaniem sugeruje zachodzenie uniwersalnego związku pomiędzy reakcjami emocjonalnymi a percepcją dzieła artysty, w ramach której rozpoznawane są dyskretne wskaźniki jego kunsztu i wirtuozerii wykonawczej. Jeśli by tak było to — zgodnie z założeniami psychologii ewolucyjnej — można by domniemywać, że związek ten jest nieprzypadkowy i wytworzony w ramach procesu ewolucyjnego, co mogłoby pośrednio świadczyć o adaptacyjnym charakterze tego typu doświadczeń. Opierając się na tych rozważaniach, Luty proponuje następnie, aby zdefiniować piękno jako „efekt biegłości (i innych kosztów), który sprawia przyjemność (niepowierzchowną, głęboką). Zwykle uważało się je za niepraktyczne. Estetyka ewolucyjna gruntownie zmienia tę perspektywę, pytając prowokacyjnie: czy istnieje coś bardziej praktycznego od piękna" (s. 159). Przyznaję, że brzmi to niezwykle interesująco, choć sądzę, że wykazanie zachodzenia jakiejś postaci koniecznego związku pomiędzy nakładem twórczej pracy i wirtuozerią, a ich dostrzeganiem w procesie odbioru dzieła sztuki, emocjami estetycznymi i odczuciem piękna wymagałoby bardziej rozbudowanej argumentacji niż ta, którą znajdujemy w tym rozdziale. Tak czy inaczej, rozdziały czwarty i piąty wydają się najważniejszymi rozdziałami książki i to w nich właśnie umieszczone zostały najciekawsze propozycje autora będące jego oryginalnym wkładem do estetyki ewolucyjnej.

Kolejny, szósty, rozdział poświęcony sztuce zwierząt i ciągłości ewolucyjnej gatunków wydał mi się podczas lektury nieco „doklejony” do głównego nurtu rozważań prezentowanych w książce. Tematyka ta sama w sobie jest interesujaca choćby ze względu na tendencję zapoczątkowaną przez samego Karola Darwina w jego słynnej pracy O pochodzeniu człowieka, aby poszukiwać w świecie zwierząt pierwotnych form zachowania i czynności poznawczo-umysłowych, jakie w bardziej wyrafinowanej postaci występują u ludzi (jest to naturalną konsekwencją przyjęcia ciągłości ewolucyjnej pomiędzy człowiekiem a zwierzęciem). Temat sztuki uprawianej przez zwierzęta pojawia się również w pracach etologów, prymatologów i estetyków ewolucyjnych, choć często trudno jest rozstrzygnąć, gdzie kończą się w tym przypadku badania naukowe, a gdzie zaczyna się sfera „doniesień anegdotycznych". Podobnie niekonkluzywne wydają się wnioski wypływające z tego rozdziału, mimo że autor deklaruje, że jest „duże prawdopodobieństwo”, iż zwierzęta (na przykład altanniki) cechują się kunsztem dekoratorskim, funkcjonalnym choćby w ramach doboru płciowego, i że nie można też „przekreślić jednoznacznie” możliwości, że zwierzęta posiadają estetyczne aspiracje (por. s. 172-173). Nie sposób się z tym nie zgodzić, choć zarazem nie sądzę, aby rozdział ten był w stanie przechylić szalę argumentacji i dowodów na rzecz którejkolwiek ze stron w sporze o to, czy zwierzęta uprawiają sztukę. 
Ostatni rozdział książki robi wrażenie nieco przeładowanego treścią, chyba ze względu na to, że musiał on pomieścić kilka odrębnych tematów: omówienie i ocenę dokonań tak zwanego literackiego darwinizmu (i na tym tle - charakterystykę koncepcji narracji Michelle Scalise Sugiyamy), omówienie zarzutów wobec podejścia ewolucyjnego, interesujące zestawienie i porównanie estetyki pragmatycznej Johna Deweya z poglądami przedstawicieli darwinowskiego ewolucjonizmu (na przykład z poglądami E. Dissanayake) oraz rozważania końcowe - obejmujące właściwie trzy ostatnie podrozdziały — w ramach których autor ocenia generalnie przydatność programu estetyki ewolucyjnej w badaniach nad sztuką oraz formułuje w kilku punktach ,zachętę" — jeśli można tak to nazwać — do rozwijania tego programu. Z konstrukcyjnego punktu widzenia przeładowanie tego rozdziału treścią nie było chyba najszczęśliwszym rozwiązaniem. Z perspektywy czytelnika oczekującego domknięcia postawionych w książce problemów i weryfikacji sformułowanych we Wprowadzeniu hipotez na temat związku uniwersalizmu estetycznego i biologicznej adaptacji, najważniejszy w tym rozdziale wydaje się fragment końcowy: „Stwierdzenie faktu istnienia uniwersaliów estetycznych (wbrew twierdzeniom estetyk relatywistycznych) — międzykulturowych i ponadhistorycznych kryteriów sztuki oraz jej oceny - sprawia, że otrzymujemy mocny fundament pod kolejne badania empiryczne, które mogłyby rozszerzyć nasze rozumienie sztuki. I chociaż przyjęcie perspektywy uniwersalistycznej w estetyce nie oznacza jeszcze automatycznie uznania sztuki za adaptację biologiczną, to jednak otwiera możliwość wielu dalszych badań" (s. 205). Fragment ten stanowi adekwatne podsumowanie wyników teoretycznych osiągniętych w książce.

$$
* * *
$$

Podsumowując, wydaje się, że przedstawiona przez Jerzego Lutego propozycja, w ramach której hipoteza o „sztuce jako adaptacji” jest weryfikowana poprzez analizę i badanie różnych form ,uniwersalizmu sztuki” jest interesującą i dobrze porządkującą opisową charakterystyką programu współczesnej estetyki ewolucyjnej, a zarazem jest to oryginalny projekt autora. Natomiast wadą proponowanego ujęcia jest, jak sądzę, to, że argumentów na rzecz szerokiego pojmowania ,sztuki jako adaptacji" dostarczają przykłady równie szerokiego rozumienia uniwersalizmu sztuki. Jest to ujęcie dopuszczalne, choć obarczone ryzykiem zbytniego rozciągnięcia pola problemowego i rozmycia wyjściowego rozumienia funkcji adaptacyjnej.

Z uwag ogólnych warto jeszcze wspomnieć o dwóch sprawach. Po pierwsze, z metateoretycznego punktu widzenia rozważania podjęte w omawianej książce można nazwać „rozważaniami programowymi” w tym oto sensie, że mają one formę dyskusji nad argumentami uzasadniającymi program estetyki ewolucyjnej. Szczególnie ciekawe wydały mi się te fragmenty książki, w których autor pokazuje wewnętrzne zróżnicowanie tego programu badawczego, poprzez przedstawienie różnicy zdań między poszczególnymi ewolucjonistycznymi koncepcjami sztuki i ich autorami, na przykład różnic pomiędzy Ellen Dissanayake i Denisem Duttonem 
w sprawie pojmowania sztuki jako adaptacji (i dodatkowo między poglądami na przykład Josepha Carolla i Stephena Daviesa). Nie mniej interesujaco zostały też ukazane w książce polemiki i dyskusje „zewnętrzne” toczone przez estetyków ewolucyjnych z autorami reprezentującymi alternatywne podejścia względem sztuki (jak dyskusje Duttona z reprezentującym podejście formalistyczne Clive'em Bellem i zwolennikiem kontekstualizmu Arthurem Danto).

Po drugie, należy na koniec zauważyć, że autor, komentując i angażując się w te polemiki, ani przez chwilę nie udaje „bezstronnego sędziego” i czytelnik przez cały czas ma świadomość, że poszczególne jego argumenty są formułowane przez zadeklarowanego zwolennika programu badawczego estetyki ewolucyjnej. Ale to akurat nie przeszkadza, jak sądzę, w lekturze, gdyż dzięki temu książka sprawia wrażenie bardziej zaangażowanej i optymistycznej poznawczo, co nie ma — moim zdaniem — negatywnego wpływu na rzetelność i dokładność analiz proponowanych przez autora.

\section{Bibliografia}

Luty J., Sztuka jako adaptacja. Uniwersalizm w estetyce ewolucyjnej, Kraków 2018. 